Ballantine, D. \& Aвbott, B. C. (1957). J. gen. Microbiol. 16, 274-281

\title{
Toxic Marine Flagellates; their Occurrence and Physiological Effects on Animals
}

\author{
By DOROTHY BALLANTINE AND B. C. ABBOTT \\ Laboratory of the Marine Biological Association, Plymouth
}

From time to time in marine, freshwater and brackish habitats water blooms, consisting of enormous local growths of algae or protozoa, occur. In the sea these are commonly known as 'red tides' or 'red water', but may be of any colour from red to brown, green, yellow or merely cloudy. These blooms may be quite harmless, but are capable of producing conditions leading to mass mortalities, which can involve fish, shellfish and other animals. The mortality may be due to actual toxins produced by the bloom, or to secondary conditions such as oxygen deficiency, hydrogen sulphide liberation as a result of decomposition, or to bacterial pollution. This paper is concerned only with marine algal flagellates which themselves produce toxins, and is, of necessity, a very limited account of these, as the literature on the subject is vast and cannot be covered in a communication of this type. Most of the information available concerns toxic flagellates which form components of 'red tides'.

\section{World distribution of marine and brackish water 'red tides'}

The map (Fig. 1) shows the world-wide distribution of 'red tides' where mortalities have been shown to occur. This is based mainly on the papers of Nightingale (1936), Brongersma-Sanders (1948) and Hayes \& Austen (1951), with additional records from other sources. This distribution map may not be complete, but gives a good illustration of the cosmopolitan distribution of the phenomenon.

The first alga we should mention is the blue-green alga Trichodesmium which is not, of course, flagellate. This forms widespread and recurrent patches in the Philippines, East Indian Archipelago and along the east coast of South America. In the Red Sea and north-west Indian Ocean blooms are due to Trichodesmium and also to dinoflagellates. Trichodesmium grows in bundles and rafts of filaments, and when forming a bloom colours the sea red by floating in dense masses on or near the surface. This appears to show a very variable toxicity, and only occasional blooms give mortalities.

The only member of the Chloromonadineae of which we have any record in toxic 'red tides' is Hornellia marina (Subrahmanyan 1954), which occurs off the south-east and south-west coasts of India.

In brackish water the Chrysophycean flagellate Prymnesium parvum Carter (1937) has been reported as causing mortalities in Denmark (Otterstrøm \& Nielsen, 1939) and more seriously in the Israeli fish ponds (Shilo \& Aschner, 1953). This organism is always present in some quantity, but can suddenly bloom and become toxic, more or less overnight. 


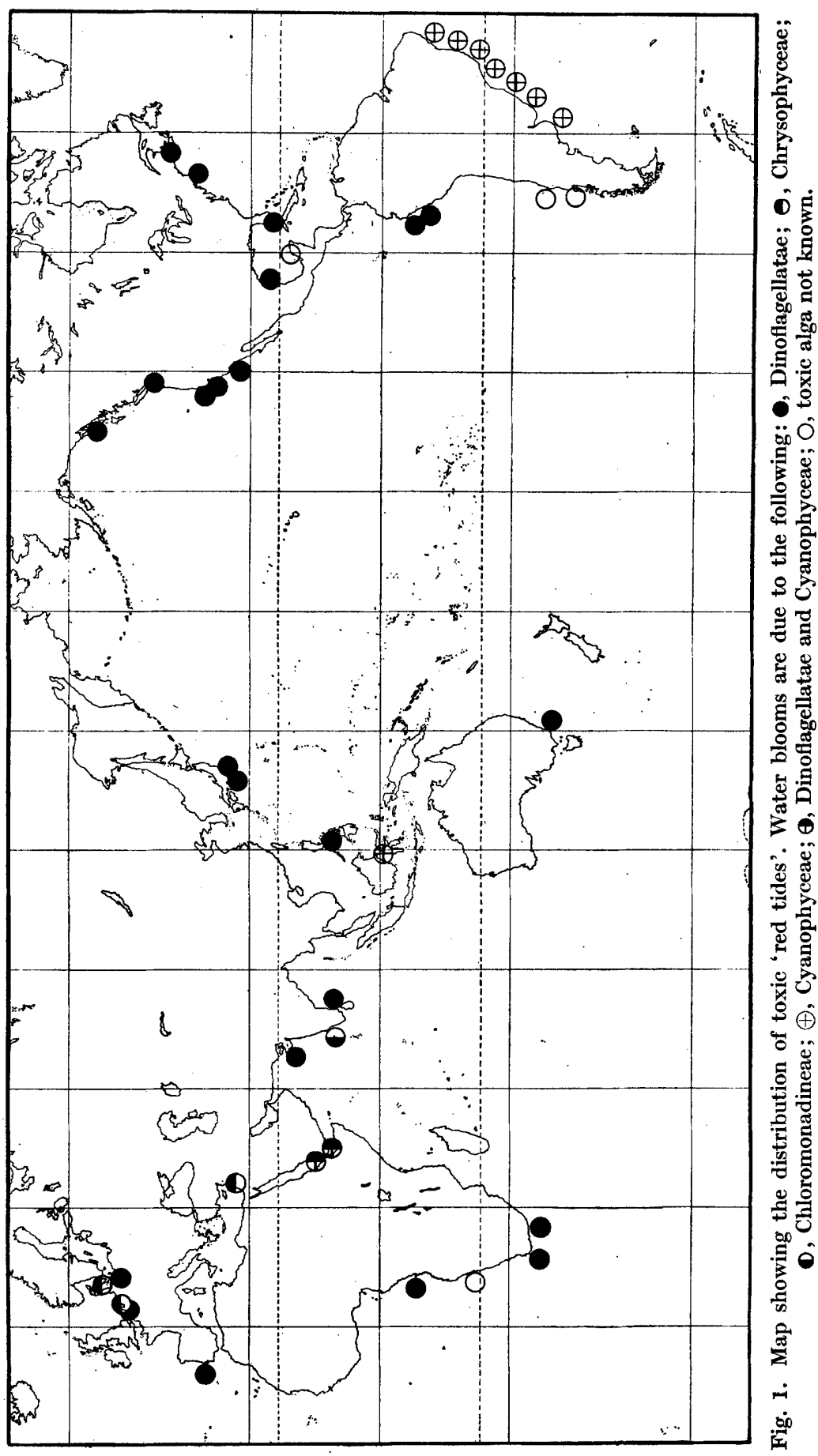


The remaining areas shaded on the map have blooms of dinoflagellates of various species, and the following is a list of some of the localities and the causative organism:

Southern California, U.S.A.: Goniaulax polyedra Stein (Kofoid, 1911); G. catenella Whedon \& Kofoid (1935).

Washington State, U.S.A. : Gymnodinium splendens Lebour (Nightingale, 1936). Florida and Gulf of Mexico: Gymnodinium brevis Davis (1948, Wilson \& Ray, 1956).

Bay of Fundy, Canada: Goniaulax tamarensis Lebour (Needler, 1949).

Belgium (Bruges-Zeebrugge canal): Pyrodinium phoneus Woloszynska \& Con$\operatorname{rad}(1939)$.

Portugal: Goniaulax polyedra Stein (Santos-Pinto, 1949).

Angola, West Africa: Exuviaella baltica Lohmann (Silva, 1956).

Japan: Gymnodinium mikimotoi Miyake \& Kominani (Miyajima, 1934); Cochlodinium catenatum Okamura (Miyajima, 1934).

Sidney, Australia: Goniaulax polyedra Stein? (Whitelegge, 1891, but see also Kofoid, 1911).

\section{Causes of 'red tides'}

Blooms occur only when a number of parameters are simultaneously suitable. This subject is by no means understood as yet, but it is obvious that high concentrations of nutrients, particularly nitrate and phosphate, must be available, temperatures must be suitable and there must also be enough phytoplankton to take advantage of these conditions while they persist. These conditions can arise in a number of ways, but among those suggested are pollution, as in the Belgian canals, by freshwater outflows rich in nutrients or by upwelling of deep cold rich water, such as occurs along the west coast of Africa from the Benguela current, and probably also in many other 'red tide' areas.

\section{Economic importance of mortalities}

The economic importance obviously depends upon the area in which the mortality occurs. The stranding of large amounts of decaying fish near areas of dense population causes a serious disposal problem and, in addition, there is frequently an irritant gas associated with 'red tides' which causes considerable discomfort (Woodcock, 1948; Ingle, 1954). There is also the loss to commercial fishing in areas around India, Florida and South America, and the damage to the oyster and other shellfish industries, particularly in Japan and America.

On the other hand, a more serious human hazard arises in the problem of paralytic shellfish poisoning (particularly in North America and Japan). Certain species of Gymnodinium and Goniaulax (e.g. Goniaulax catenella and G. tamarensis) bloom in inshore waters and shellfish which feed on the flagellates may not be killed but concentrate the poison in their digestive glands. When these shellfish are eaten they can cause serious illness or death. This toxin is thermostable and survives cooking and even canning. It produces vomiting, facial paralysis, later extending to the limbs, and death in severe cases from respiratory paralysis (Dodgson, 1928). 
A great deal of work has been done in America on the ecology of the species involved, the hydrographical conditions of the affected areas, and the pharmacology of paralytic shellfish poison, and it is beyond the scope of the present paper to do more than briefly mention this most important contribution. In view of the human problems involved the emphasis has been on the medical and preventive aspects. Extracts from the digestive glands of the poisoned mussels have been prepared and injected into mice, and by this means a bioassay technique has been developed (Stephenson, Edwards, MacDonald \& Pugsley, 1955). The poison has also been extracted from phytoplankton and the connexion between the two established (Sommer, Whedon, Kofoid \& Stohler, 1937; Riegel, Stanger, Wikholm, Mold \& Sommer, 1949). It is now possible by routine examination of phytoplankton samples to determine the times of year at which dangerous degrees of toxicity are likely to occur. Chemical analysis has also been attempted, and study of the pharmacological action of the toxin, in an effort to determine the exact composition of the toxin, but so far nothing has been published on this subject, though it is known that the compound is basic in nature. So far as we know no work has been done with bacteria-free cultures of toxic marine flagellates, but evidence at present indicates that the flagellates themselves produce the toxins.

\section{Physiological effects of the toxins from marine algae}

Our interest in the problem of red tides was stimulated by the discovery of a new species of dinoflagellate, Gymnodinium veneficum, which proved to be toxic. This species was isolated by Dr Mary Parke from the Plymouth area and described by one of the authors (Ballantine, 1956). The flagellate is about $12 \mu$. long, yellowish brown in colour and is a phototrophe; it produces a very powerful toxin, most of which is secreted into the water. No red tides occur near Plymouth, nor have there ever been any reports of fish mortalities or of poisonous shellfish due to this cause. It has therefore been possible to investigate the mode of action of the G. veneficum toxin without the emphasis of a problem in preventive medicine.

Experiments have been carried out with a wide range of animals, and all except polychaetes are affected to a greater or lesser extent. In particular small fish, mainly gobies, have been used as test animals; these die within $10 \mathrm{~min}$. in toxic cultures. Death in fish seems to be due to some form of respiratory failure. The action of the toxin is certainly on the nervous system. The first symptoms are a complete loss of balance, combined with an intense change of colour pattern. This is followed by a period of violent gasping, and intermittent unco-ordinated bursts of movement. During the quiescent intervals, which become progressively longer, there is no response to sensory stimulation. At the point of death there is no sign of haemolysis in the blood, the heart is beating, and excised muscles respond to direct stimulation. In the case of the frog, injection of the toxin into dorsal lymph sac has an immediate paralysing effect. Sensory stimulation has no effect and breathing stops completely. Yet the frog may live in this paralysed state for a couple of days before dying; the necessary oxygen supply is provided by exchange through the skin. 
The Gymnodiniumveneficum toxin has been obtained salt-free by dialysis and concentrated by evaporation under reduced pressure. Its effects on isolated tissues from a variety of animals have been studied. Only a few conclusions can be mentioned here. The toxin acts by depolarizing excitable membranes, rendering them inexcitable. Both nerves and muscles are affected, but in the intact animal death occurs because of interference with transmission in the nervous system. The effect is reversible in isolated tissues, but the whole animal cannot dispose of the toxin. Isolated hearts from most animals can be inhibited by the toxin. Buccinum undatum (whelk) is particularly sensitive; the heart stops in systole and can be used for bioassay. Frog sartorius muscle

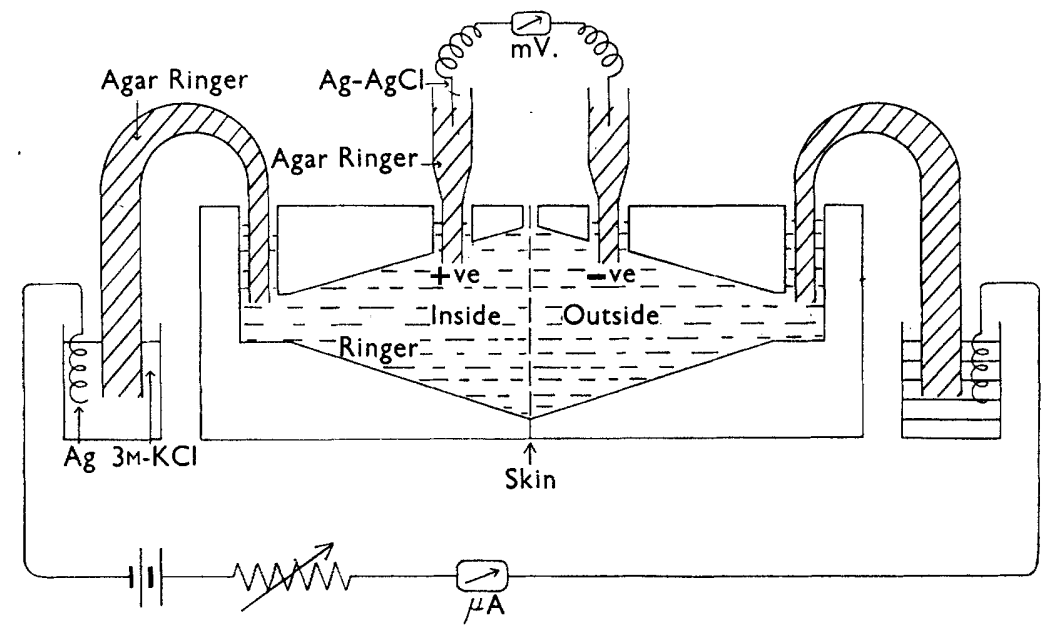

Fig. 2. Apparatus for measurement of potential and resistance of isolated frog skin (after Ussing; for explanation see text).

becomes inexcitable both to indirect (nerve) and to direct (muscle) stimulation. Membrane potentials were measured by inserting a micro-electrode into the muscle fibre; the resting potential of about $80 \mathrm{mV}$. drops to a very small value within a few minutes of application of the toxin, and excitability disappears.

This effect was studied in more detail in frog skin. Isolated skin, even with identical Ringer solution on both sides, shows a potential difference of about $50 \mathrm{mV}$. between the two sides, with the inside positive. This potential drops to zero within a few minutes of the addition of Gymnodinium veneficum toxin to the inside of the skin. The apparatus used in these experiments is shown in Fig. 2, and is adapted from that described by Koefoed-Johnsen, Ussing \& Zerahn (1952). A circular piece of skin isolated from the abdominal surface of the frog separates two conical chambers cut in Perspex. Skin potential is recorded from the two electrodes near the skin, one on either side. Current can be forced through the skin from an external battery through the two outer silver electrodes via agar bridges. From the relation between the external current imposed and the resultant potential measured across the skin, a measure of the total skin resistance can be obtained. 
The equivalent circuit of the skin, based on Ussing \& Zerahn (1951), is shown in Fig. 3. A sodium pump in the skin forces sodium ions across the skin, and the result can be represented by a battery $E_{N}$ in series with a resistance which opposes the flow of the sodium ions. The passive resistance of the skin to other ions acts as a resistance in parallel to the battery circuit. The thin lines show the meter for recording skin potential and also show the external circuit for imposing an extra current through the skin. When the imposed current is varied the recorded skin potential varies, and the slope of the current-

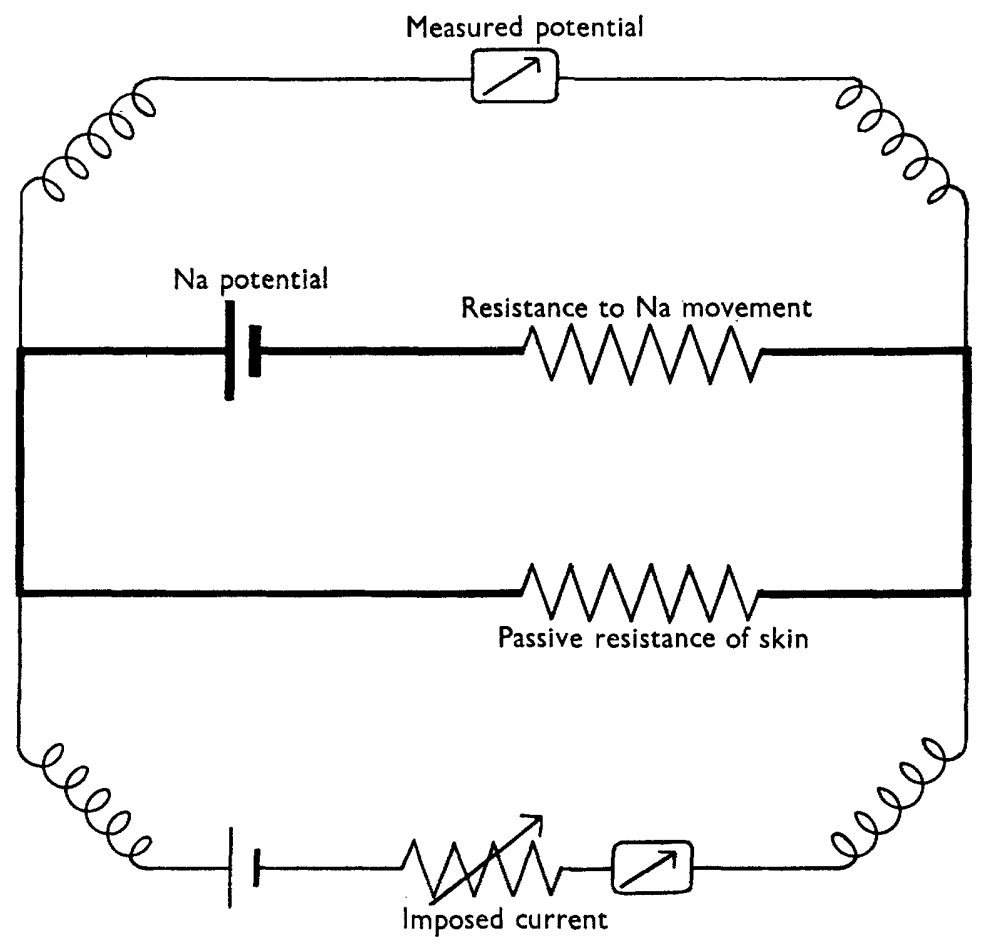

Fig. 3. Equivalent electrical circuit of frog skin (after Ussing; for explanation see text).

voltage relationship provides an indication of the total skin resistance offered (it actually gives the sum of the conductances of the two paths). From the equivalent circuit it can be seen that the skin potential could be destroyed either by inhibition of the sodium pump or by a very large decrease in the passive skin resistance-which would effectively short circuit the battery $E_{N}$. We have found that the skin resistance is completely unaltered by the addition of the Gymnodinium veneficum toxin. In contrast, destruction of the membrane potential by the addition of potassium chloride is associated with a 12-fold increase in the conductance of the skin.

From this and other results it is concluded that the flagellate toxin affects the exchange of sodium ions across cell membranes. It has not so far been possible to specify the main sites of action in a whole animal, whether in the central or 
peripheral nervous system. Death certainly occurs before the skeletal muscle system has become inexcitable to direct stimulation. But in general we have found that well-sheathed nerves are less affected than muscle tissue, whereas exposed sensitive nerve endings are rapidly inhibited. Experiments on transmission through mammalian superior cervical ganglia have shown that ganglionic potentials can be depressed, with particular emphasis on the disappearance of the slow after-potential.

Studies by Kellaway (1935) and by Fingerman, Forester \& Stover (1953) showed that the toxic extracts from 'livers' of poisonous shellfish act on the nervous systems of mammalian and amphibian animals. Fingerman et al. concluded that this toxin acted in a manner similar to curare, by preventing the response of skeletal muscles to acetylcholine.

The toxin from Gymnodinium veneficum is probably different from the shellfish poison. We have reported in more detail (Abbott \& Ballantine, 1957) that extraction of the $G$. veneficum toxin under acid conditions, similar to those used for shellfish extraction, alter the action of the poison. But if the $G$. veneficum toxin is extracted under neutral conditions the effect on frog nerve-muscle preparations is very like that described by Fingerman et al.: loss of indirect excitability first, at which stage end-plate potentials can be recorded, followed by disappearance of the end-plate potentials and eventual loss of excitability in the motor nerve. But in the case of the $G$. veneficum toxin the effect is due to membrane depolarization rather than to a curare-like inhibition of response to acetylcholine.

\section{REFERENCES}

Aввott, B. C. \& Baldantine, D. (1957). The toxin from Gymnodinium veneficum Ballantine. J. mar. biol. Ass. U.K. 36, 169.

Ballantine, D. (1956). Two new marine species of Gymnodinium isolated from the Plymouth area. J. mar. biol. Ass. U.K. 35, 467.

Brongersma-Sanders, M. (1948). The importance of upwelling water to vertebrate paleontology and oil geology. Verh. Akad. Wet. Amst. 45 (4)

Carter, N. (1937). New or interesting algae from brackish water. Arch. Protistenk. 90, 1.

Davis, C. C. (1948). Gymnodinium brevis n.sp. a cause of discolored water and animal mortality in the Gulf of Mexico. Bot. Gaz. 109, 358.

Dodgson, R. W. (1928). Report on mussel purification. Fish. Invest., Lond. Ser. Ir, 10 (1).

Fingerman, M., Forester, R. H. \& Stover, J. H. (1953). Action of shellfish poison on peripheral nerve and skeletal muscle. Proc. Soc. exp. Biol., N.Y. 84, 643.

Hayes, H. L. \& Austen, T. S. (1951). The distribution of discolored sea water. Tex. J. Sci. 3, 530.

INGLe, R. M. (1954). Irritant gases associated with Red Tide. Florida, Univ. Miami Mar. Lab., Spec. Service Bull. no. 9.

Kellaway, C. H. (1935). The action of mussel poison on the nervous system. Aust. J. exp. Biol. med. Sci. 13, 79.

Koefoed-Johnsen, V., Ussing, H. H. \& Zerahn, K. (1952). The origin of the shortcircuit current in the adrenaline stimulated frog skin. Acta physiol. scand. 27, 38. 
KoFoID, C. A. (1911). Dinoflagellata of the San Diego region. IV. The genus Gonyaulax, with notes on the skeletal morphology and a discussion of its generic and specific characters. Univ. Calif. Publ. Zool. 8, 187.

MiYaJima, M. (1934). La question de l' 'eau rouge', un péril pour les huîtres perlières. Bull. Soc. cent. Aquic. Pêche, 41, 97.

Needler, A. B. (1949). Paralytic shellfish poisoning and Goniaulax tamarensis. J. Fish. Res. Bd Can. 7, 490.

Nightingale, H. W. (1936). Red Water Organisms: their Occurrence and Influence upon Marine Aquatic Animals, with Special Reference to Shellfish in Waters of the Pacific Coast. Seattle, Washington: Argus Press.

Otterstrøm, C. V.\& Nielsen, E. S. (1939). To 'Tilfaelde af omfattende Dødelighed hos Fisk foraarsaget af Flagellaten Prymnesium parvum Carter. Rep. Danish biol. Sta. 44, 5.

Riegel, B., Stanger, D. W., Wikholm, D. M., Mold, J. D. \& Sommer, H. (1949). Paralytic shellfish poison. V. The primary source of the poison, the marine plankton organism, Gonyaulax catenella. J. biol. Chem. 177, 7 .

Santos-Pinto, J. (1949). Un caso de 'red water'motivado por abundancia anormal de Goniaulax poliedra Stein. Bull. Soc. portug. Sci. nat. 11, 2nd Ser. 17, 94.

Shilo, M. \& Aschner, M. (1953). Factors governing the toxicity of cultures containing the phytoflagellate Prymnesium parvum Carter. J. gen. Microbiol. 8, 333.

Silva, E. S. (1956). 'Red Water' por Exuviaella baltica Lohm. com simultânea mortandade de peixe nas águas litorais de Angola. Trabalhos da Missão de Biologia Maritima (Lisboa) 1953. Publ. 1956.

Sommer, H., Whedon, W. F., Kofoid, C. A. \& Stoliler, R. (1937). Relation of paralytic shell-fish poison to certain plankton organisms of the genus Gonyaulax. Arch. Path. (Lab. Med.), 24, 537.

Stephenson, N. R., Edwards, H. I., MacDonald, B. F. \& Pugsley, L. I. (1955). Biological assay of the toxin from shellfish. Canad. J. Biochem. Physiol. 33, 849.

Subrahmanyan, R. (1954). On the life history and ecology of Hornellia marina gen. et sp.nov. (Chloromonadineae), causing green discoloration of the sea and mortality among marine organisms of the Malabar coast. Indian J. Fisheries, $1,182$.

Ussing, H. H. \& Zerahn, K. (1951). Active transport of sodium as the source of electric current in the short-circuited isolated frog skin. Acta physiol. scand. 23, 110.

Whedon, W. F. \& Koford, C. A. (1935). Dinoflagellata of the San Francisco region. 1. On the skeletal morphology of two new species, Gonyaulax catenella and G. acatenella. Univ. Calif. Publ. Zool. 41, 25.

Whitelegge, T. (1891). On the recent discoloration of the waters of Port Jackson. Rec. Aust. Mus. 1, 179.

Wilson, W. B. \& RAY, S. M. (1956). The occurrence of Gymnodinium brevis in the western Gulf of Mexico. Ecology, 37, 388.

Woloszynska, J. \& Conrad, W. (1939). Pyrodinium phoneus n.sp., agent de la toxicité des moules du canal maritime de Bruges à Zeebrugge. Bull. Mus. Hist. nat. Belg. 15, (46) 1.

Woodcock, A. H. (1948). Note concerning human respiratory irritation associated with high concentrations of plankton and mass mortality of marine organisms. J. mar. Res. 7, 56. 